\title{
The Euro's Future: A Ten-Year Projection
}

Balasundram Maniam, Sam Houston State University, USA

Tony Mouser, Sam Houston State University, USA

Hadley Leavell, Sam Houston State University, USA

\begin{abstract}
The euro is now more than ten years old. It has not quite lived up to the early expectations but has performed well since its introduction. This paper seeks to review the currency's history and evaluate its potential over the next ten years given a list of currency strength factors. This evaluation was based on a thorough review of available research regarding the topic. This paper finds that, despite some significant weaknesses, both the currency and its underlying economy are relatively strong and poised to grow in the long-term. As such, it makes the case for an appreciated currency in the next ten years.
\end{abstract}

Keywords: Euro; European Central Bank

\section{INTRODUCTION}

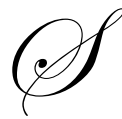

ince the euro's debut in 1999, many have predicted that it will ultimately surpass the United States' dollar as the world's preeminent currency. Although far from achieving that feat, the euro has been gaining momentum since its introduction. Given this modest level of success, it seems pertinent to evaluate how the currency will fair over the next ten years.

The purpose of this paper is to explore the euro's beginnings and evaluate the currency's future prospects. This evaluation includes a review of some economic strength gauges, such as economic size and growth, inflation, current account balances, and fiscal policy. These discussions will be followed up with a review of the currency's demand profile as characterized by its international usage and foreign currency reserve weightings. Each of these areas will also include comparisons against the United States' economy and the dollar. The findings from all these discussions will be used to project the euro's direction in relation to other currencies over the next ten years.

Before delving into the various aspects of a currency's strength, it is important to first review the euro's history and the factors contributing to its introduction.

\section{BACKGROUND}

After devastating and demoralizing wars in the early twentieth century, European leaders decided that the best course for establishing long-lasting peace was to unify economically. The Treaty of Rome (1957) was one of the first attempts at unification. It formed the European Economic Community, which in 1969 commissioned a group, led by the Prime Minister of Luxembourg, to research and establish a blueprint for monetary and economic union. The goal was to implement these policies by 1980. However, severe global currency market disruptions in the 1970s derailed these plans. In 1989, European leaders renewed their unification hopes with the development of the Delors proposal. This plan introduced the idea of the European Central Bank. The proposal was largely accepted and integrated into the euro's conceptual framework as the Treaty of Europe (Dominguez, 2006). The timetable established by the Delors proposal was faithfully followed and led to the January 1999 adoption by eleven European countries of the euro as their official currency. Membership has since grown to seventeen countries with the June 2010 inclusion of Estonia.

The European Central Bank's policies are crucial to the euro's future strength so it is imperative to explore the bank's structure, role, and objectives before proceeding further. 
The European Central Bank (ECB) was officially established in June 1998 under several treaties signed by the original Euro area nations. These nations empowered the ECB by transferring their monetary policy responsibilities in 1999. The ECB is comprised of three decision making bodies: the governing council, executive board, and the general council. Membership for these positions is currently at thirty-three. The governing and general councils are appointed by their home countries while the executive board members are appointed by consensus among the Euro area's heads of state.

The effectiveness of the European Central Bank is dependent upon its staff members remaining independent. In fact, independence is emphasized throughout the ECB constitutional framework, which urges members to refrain from seeking advice or instructions from government officials. Political influence can become disruptive and can serve only limited constituencies. By remaining independent the ECB can focus on the best strategies to accomplish its objectives.

According to the European Central Bank's mission statement, it works in conjunction with other European Union national banks to focus primarily on maintaining policies that support pricing stability. Accordingly, the ECB believes that maintaining stable prices is paramount to the development of economic welfare and growth opportunities. Pricing stability is defined by the Governing Council as an annual increase in the "Harmonised Index of Consumer Prices" (HICP) of less than two percent. To accomplish this goal, the ECB adjusts interest rates, issues bank notes, and establishes banking reserve requirements.

By effectively maintaining pricing stability, the ECB will play a critical role in ensuring that the euro strengthens versus other currencies. As such, the bank will be mentioned throughout this paper.

\section{LITERATURE REVIEW}

The introduction of the euro has been a momentous event in contemporary finance. It has had a profound global impact that will last for generations. Accordingly, a vast amount of research has been dedicated to the subject in recent years.

Kathryn Dominguez (2006) provided some insight into the euro's history and elaborated on the currency's framework. She also explored the European Central Bank's basic monetary policies. Kathryn further evaluated the currency's global role and finished her discussion with concerns regarding the euro's looming challenges.

In 1995, Jeffrey Frankel wrote "Still the Lingua Franca", an article in which he projected that the euro would not challenge the dollar for supremacy in the near future. He questioned the popularized theory that the dollar was faltering. Although he admitted that the U.S.' GDP performance has not been ideal, he characterizes much of the dollar's negative sentiment as short-sighted.

Honohan, Lane, Ventura, and Begg researched recent reports of divergent inflation rates throughout the EMU (2003). They studied data from 1972 through 2003 and hypothesized that divergence was directly related to exchange rate movements and were more noticeable in accession years. Honohan, Lane, Ventura, and Begg also found that the ECB's policies had a stabilizing effect on the region. Finally, the authors concluded that the United States historically experienced a greater degree of divergence than the EMU.

In 2003, Galí, Perotti, Lane, and Richter evaluated the effects of both fiscal and monetary policy in the Euro area. They challenged recent critisms of the Maastricht Treaty and Growth and Stability Growth Pact. The authors conducted empirical research and found no evidence to support the fiscal policy impairment claims. Furthermore, the authors discovered support indicating improved responses to economic vicissitudes.

Olivier Blanchard evaluated the Euro area's economy in 2004 and used these observations to project the region's economic prospects. Included in this discussion were GDP, productivity, labor markets, unemployment policies and a variety of other topics. Overall, Olivier projected a more optimistic future for the region, based on improving productivity measures. 
In 2005, Goldberg, Engel, and Portes studied the trade invoicing practices of current EMU members and assessed the trade potential for accession candidates. The authors provided a list of determinants in selecting the optimal currency to use in international transactions. They also reviewed countries that predominantly invoice in euros.

Finally, Kaminskey, Lizondo, and Reinhart in 1998 documented some general economic factors that are indicative of currency weaknesses, which could be useful in evaluating the euro. This International Monetary Fund workpaper was written in the wake of several Asian currency crises in hopes of preventing or predicting future catastrophes.

The discussion above provides a brief summary of some of the more influential articles pertaining to the euro and its underlying economy. The next section will re-introduce the currency strength factors, which will segue into a performance evaluation for each category.

\section{CURRENCY STRENGTH EVALUATION FACTORS}

To evaluate the euro's currency strength ten years from now, it is important to first establish criteria for measuring this competency. Currencies are dynamic and change in value for a variety of reasons. Valuations are generally based on comparisons with other currencies and evaluated based on future prospects. Many economists have indicated that the strength of a currency is greatly related to the underlying performance of the supporting economy. Therefore, it is imperative to evaluate the economy to properly forecast the strength of a currency years into the future. For the purposes of this discussion, several criteria have been selected to evaluate the euro area. They are economic size and growth, inflation levels, fiscal policy, as well as the national current account. These criteria have been selected from the International Monetary Fund's long list of influential currency variables (Kaminsky, Lizondo, \& Reinhart, 1998).

Another important aspect to consider when evaluating a currency's strength is its demand profile. It includes international usage and foreign currency reserve weightings. These factors have an interrelated-causal relationship with the factors mentioned above. While demand can be a strength measure, it can contribute to it as well.

The following sections will explain each currency strength factor, followed by a discussion of the Euro area's performance in each category. Then, the euro's performance will be compared with the U.S. dollar.

\section{ECONOMIC SIZE AND GROWTH}

Economic size and growth is one of the most important factors when contemplating a currency's relative strength to its peers. These attributes are best measured by national output, or Gross Domestic Product (GDP). GDP is one of the primary indicators for evaluating an economy's health. The larger the economy supporting the currency the more confidence the markets have in the currency's liquidity. Larger economies also offer sanctuary from external blows while providing larger capital markets for foreign investment (Bergsten, 1997).

Historically, the Euro area's annual GDP growth rates have underperformed the other major economies. Specifically, the Euro area's output grew twenty-nine percent compared to the United States' forty-five percent from 1990 to 2004 (Blanchard, Giavazzi, \& Sa, International Investors, the U.S. Current Account, and the Dollar, 2005). Hans-Jürgen Bieling, a political science professor at the Phillips-Universität Marburgin in Germany denounced the area's economic growth over the past thirty years as "mediocre". He attributes the problems in the early 2000s to the European Central Bank's exclusive focus on inflation and the Stability and Growth Pact's governmental spending restraints (Bieling, 2006).

Although growth in the Euro area has not been ideal, other developments point towards a more promising future. Gross Domestic Product per hour worked has increased substantially since 1970. The region has become more efficient as a result of monetary unionization. Oliver Blanchard makes the case that if Euro area workers were to work the same hours as their American counterparts, their productivity per capita would be far superior 
(Blanchard, The Economic Future of Europe, 2004). It is questionable; however, whether the differential in hours worked was due to leisure or unemployment.

Another important aspect when considering a currency's strength is the sheer size of the underlying economy. The Euro area's gross domestic product is second only to the United States'. The EA's 2008 GDP was EUR 9.209 trillion, or USD 13.475 trillion when converted using the year's average exchange rate of 1.4633 USD/EUR. This compares with the U.S.' 2008 GDP of USD 14.441 trillion. While it is true that more recent GDP comparisons will factor in a weakened euro, the Euro area productivity is closing in on the reigning GDP leader. In fact, it seems only a matter of time before this actually occurs. Nine more countries are expected to join the Economic and Monetary Union (EMU). Original plans were for all twenty-seven European Union countries to join the EMU; however, it seems that the United Kingdom has no intention of retiring the pound or joining the union. Nevertheless, had the remaining countries currently awaiting admittance to the union been included in 2008's GDP calculations, the revised number would have been USD 15.650 trillion. This would catapult the Euro area past the United States' as the world's largest economy.

Overall, the economic growth and size aspects for the Euro area should be considered a strength going forward. Despite Beiling's accurate observations concerning the Euro area's disappointing organic growth in GDP, the region should benefit from the efficiency improvements noted by Blanchard. The Euro area GDP should also increase as a result of adding other European Union countries. As a result, many economists project the EMU to be the world's largest economy within the next ten years. As a result, more transactions would be denominated in euros, the currency's visibility in the marketplace would increase accordingly. These factors would contribute to a strengthening euro.

Although economic growth and size are one of the most influential factors, its counterpart, inflation, can prove vitally important to currency strength discussions. The next section will introduce this topic and discuss the European Central Bank's role in influencing it.

\section{INFLATION}

Another important metric to consider when projecting a currency's strength relative to peers is inflation. Inflation has a proven impact on a currency's exchange rate by virtue of the Fisher effect. As such, any increase in expected inflation will cause a proportionate increase in domestic interest rates. This rise in interest rates will increase the money supply, resulting in a depreciating exchange rate, ceteris paribus. Investors generally seek asset investments in countries with low and predictable inflation rates. Consequently, economies with lower inflation should experience greater foreign demand for their domestic currencies.

One of the primary goals in establishing the Economic and Monetary Union was to control pricing instability within the European Union. Accordingly, the European Central Bank's primary monetary policy tenet is to maintain pricing stability as mandated by the Treaty Establishing the European Community. The Governing Council has since defined this metric using the Harmonized Index of Consumer Prices (HICP) for the Euro area. The current goal is to maintain the HICP index at or below two percent per year for the entire region.

On the surface, it seems that the ECB has effectively attained its goal. Its HICP growth has been very comparable with American inflation as measured by the U.S. consumer price index over the past ten years. However, it should be noted that the definition of HICP is ambiguous and may not provide a valid comparison with United States' published inflation figures. The two measurements have stark conceptual differences. One journal article claims that the HICP is not a cost of living index at all and raises serious questions regarding its accuracy. (Cecchetti, Wynne, Galí, \& and Propper, 2003). The authors, however, concluded that other reputable indexes are inaccurate at times due to inherent biases. The main reason for their concern is the lack of guidance as to the necessary adjustments that are made, if any. Furthermore, the HICP results are difficult to replicate.

Another concern is the level of inflation divergence within the Euro area. From 1999 through 2002, Ireland, Greece, the Netherlands, Portugal and Spain experienced the highest inflation rates, varying between 3.1\% and $4.1 \%$ compared with the EMU average of $2.5 \%$ (Honohan, Lane, Ventura, \& and Begg, 2003). After 
conducting similar statistical analyses on the United States and the EMU, the authors concluded that the inflation divergence within the U.S. was larger. Although that may be the case for the study, it is still noteworthy nonetheless that the European Central Bank is ill-equipped to target specific regions. The ECB's tactics are limited to largescale interventions.

The Euro area's inflation potential should be considered a weakness at this point. Despite having respectable comparisons with the United States, the future inflation expectations are difficult to project. The lack of clarity on the ECB's HICP calculations is concerning and additional modifications may be necessary to ensure improved accuracy in the future. Various studies have shown that inflation levels using different metrics have improved throughout the Euro area since unionization. This is a good sign. But the Euro area is still early in its development and the ECB's limited powers have not been fully tested under inflationary pressures.

\section{CURRENT ACCOUNT}

An economy's annual current account, also called the balance of payments, is another important metric for predicting a currency's future potential. The current account represents net payments and cash receipts from transactions with other countries. It includes such categories as exports, imports, foreign investment income, and unilateral transfers (charity and aid) to other countries. There are a myriad of macroeconomic factors that impact the current account. Some examples include trade policies, interest rates, gross national product, investment opportunities, and foreign exchange rates. It is important to keep these factors in mind when interpreting current account balances.

Since its inception, the Economic Monetary Union has maintained a strong current account position. The union has had account surpluses in five of the eleven years it has been in existence. The deficits experienced seem immaterial when compared to the region's overall GDP. The deficit outliers were years 2000 and 2008, both global recessionary periods. These incidents were most likely attributable to the relative weakness in the U.S. dollar that stifled demand for Euro area goods.

By contrast, the U.S. has incurred increasing current account deficits each year. Its account deficit has grown from $\$ 398$ billion in 2001 to 706 billion in 2008 (Flatness, Whitake, \& Yuskavage, 2009). Ordinarily, these deficits would eventually lead to a weakened dollar, assuming other countries used the proceeds from these imbalances to invest in other economies' financial markets. This has not happened, however, since foreign countries have invested their surpluses in American governmental debt. Another contributing factor is the high global demand for American investments (Exchange Rate Conundrums, 2003). This has artificially strengthened the dollar and made American goods overpriced compared to foreign offerings, thus making them less competitive. Overall, America's excessive debt burden in addition to its rapidly increasing deficits is quite alarming.

As such, the Euro area's current account should be considered a strength when compared with that of the United States'. Although the Euro area current account balance is still in negative territory at the present time due to the recession, it is expected to improve as the global recovery becomes more pronounced (Davis, 2010). This assessment seems reasonable as it is consistent with prior period trends.

Two primary tools employed by government officials to guide the economy are monetary and fiscal policy. Monetary policy was mentioned earlier in both the inflation and background sections. The other tool, fiscal policy, is also instrumental in supporting a currency's strength. Accordingly, a more detailed discussion follows below.

\section{FISCAL POLICY}

Fiscal policy refers to governmental revenue and spending policies used to influence economic activity. Governmental spending can encourage entrepreneurial development and industrial diversification. It can also soften the shocks of economic hardships, originating both internally and externally. The buffering effects, therefore, can improve an economy's potential to support a strong currency. There are limitations however. Countries that spend beyond their revenue, or tax receipts, will effectively dilute their currencies. To complicate matters further, unlike the independent central bankers, fiscal policy is subject to political whims arising from constituent and exogenous 
pressures. It is obviously a daunting task to maintain an effective fiscal policy. But, if achieved, the benefits to currency strength are numerous.

The European Economic and Monetary Union's biggest challenge is the absence of a coordinated fiscal policy. Unlike the United States where fiscal policy is determined centrally, the EMU is organized such that each of the seventeen member nations establishes its own governmental revenue and expenditure directives. However, these initiatives are substantially limited by the Maastricht Treaty and the Stability and Growth Pact. These provisions limit spending in excess of three percent of annual GDP. Additionally, these rules restrict a nation's total debt to sixty percent of GDP. If either of these stipulations are violated, the country will face "excessive deficit procedures", which generally involve greater restrictions and, in some cases, punitive actions. There are allowances for recessionary periods or other major catastrophes.

The Maastricht Treaty and the Growth and Stability Pact have been controversial. Respected Greek professor Theodore Pelagidis and Lloyd's of London senior analyst Evangelia Desli contend that these policies provide barriers to growth that will ultimately undermine the euro's credibility (Pelagidis \& Desli, 2004). Others are concerned that the Stability and Growth Pact limits countries' ability to offer governmental services and build public infrastructure. However, authors Galí, Perrotti, Lane, and Richter conducted empirical studies and concluded that none of these claims held true (Galí, Perotti, Lane, \& Richter, 2003). Geoffrey Garret of Yale University is even more optimistic since he believes that the stability pact rules will not be enforced and will be administered with a great deal of flexibility (Garrett, 2000). Geoffrey's assessment seems valid but raises another concern. If the rules were disregarded, this could undermine European Central Bank policies, thus making their objectives much more difficult to accomplish.

The Euro area's fiscal policies are much weaker than those of the United States' as they are more difficult to implement and are subject to stiff limitations. Although the Maastricht Treaty and Growth and Stability Pact seek to limit irresponsible and excessive spending, their effectiveness and enforcement measures are questionable. Given that fiscal policy is really the sole economic tool available to Euro area's governmental heads, this is significant blow to currency strength arguments.

The previous discussions were dedicated to evaluating a currency's home economy performance as it relates to currency strength. The following sections will discuss the currency's role in international trades and relate more directly to currency demand.

\section{CURRENCY USAGE}

Currency usage is generally measured by the percentage of global trade transactions invoiced in a particular currency even if the currency's home country is uninvolved. Several factors are considered when selecting the best currency to use in global transactions. Chief among them are availability, volatility, and pricing stability. Regardless of the rationale, however, the currency of choice will gradually strengthen in relation to its peers. Accordingly, a transactional usage discussion is warranted whenever contemplating the future of a currency.

The euro's usage and visibility have increased substantially since its 1999 introduction. In five short years, the euro's involvement in global transactions outside the EMU increased from 20.8 percent to 27.7 percent (Kamps, 2006). Despite this positive development, the currency was by far overshadowed by the U.S. dollar in 2004. During this period, the dollar was involved in at least one side of a global transaction 88.7 percent of the time. By contrast, the euro was involved in only 37.2 percent of all transactions (Goldberg, Engel, \& Portes, 2005).

The euro's prospects are brightening, however. Annette Kamps concluded that the euro's role in currency transactions has been ever increasing as more countries are admitted into the Economic and Monetary Union (Kamps, 2006). Many others have shared this view since the euro's debut in 1999. Although at that time, many believed the United Kingdom would not hesitate in joining the union. Despite their reluctance, there is still considerable room for growth in EMU membership. Therefore, it is reasonable to expect the euro to gain traction within the upcoming decade with nine potential additions to the EMU on the horizon. 
As a result of additional accessions to the union and favorable trade invoicing trends, the euro seems destined to become more involved in global transactions. Although the currency is still lagging the dollar in global involvement, the euro's expected increase in usage is viewed as a strength. Consequently, this factor should favor a strengthening euro for some time to come.

The importance of the involvement in global trade cannot be over-emphasized. In fact, some believe that this type of exposure is a primary determinant in a central bank's decision to denominate reserves in a particular currency, which is the focus of the next section (Portes, Rey, De Grauwe, \& Honkapohja, 1998).

\section{FOREIGN CURRENCY RESERVES}

Foreign currency reserves refer to other central banks' holdings in a particular currency and directly impact a currency's demand. A currency's foreign reserve weighting and its relative exchange rate strength are interrelated. Generally, as foreign banks accumulate larger quantities of a currency, the resulting global demand increases, resulting in a strengthening versus peers, all else held constant. The reverse can be true as well. If central banks perceive a long-term appreciation pattern, they are more apt to accumulate and hold those currencies in their reserves. Either way, foreign currency reserve weightings are important to a currency's future strength. Thus, a thorough evaluation of reserve trends could reveal some indication as to the direction of a currency's exchange rate.

The Euro has increased its weight in known global foreign reserves from 18.2 percent in 1999 to approximately 27.4 percent in 2009 (Currency Composition of Official Foreign Exchange Reserves, 2010). These figures are limited in that they are based on only fifty-six (2009) to seventy-seven (1999) percent of the global foreign currency reserves. In addition, a significant portion of the euro's increase is attributable to a sharp appreciation in its exchange rate from 2000 to 2002 (Force, 2006).

The euro has gained ground and seemingly at the dollar's expense. Although the dollar remains the preeminent foreign reserve currency, its weighting has decreased from 71.0 percent to 62.1 percent of known global reserves over the past ten years (Currency Composition of Official Foreign Exchange Reserves, 2010). The dollar's decline is most likely attributable to the euro's surge in exchange rates referenced earlier. Nevertheless, as mentioned above, appreciation trends can lead central bankers to pursue higher reserve levels of a particular currency over time.

The euro's foreign reserve trend appears promising and should be viewed as an overall strength. Although much of the previous increase has been related to foreign exchange movements, the currency's fundamentals have been improving. Measures of these fundamentals include economic size, financial market development, historical stability, and global market confidence in the currency's value (Frankel, 1995). As indicated in earlier discussions, the euro and the underlying Euro area economy have shown a great deal of improvement in these areas, especially when contemplating the prospects of additional accessions to the monetary union.

This section concludes the review of the factors contributing to a currency's strength relative to its peers. The following discussion will collectively evaluate these factors to form an opinion about the Euro's ten-year trajectory.

\section{IMPLICATIONS FOR THE EURO}

The euro has several strengths supporting a stronger exchange rate in coming years. Although the Euro area currently underperforms the American economy in terms of GDP growth, the region's trends point towards a promising future. Growth is supported by improved GDP per capita performance and potential accessions to the Economic and Monetary Union. The Euro area's current account is by far superior to that of the United States. It has historically been a net exporter and has experienced significant account surpluses. Despite recent deficits due to the global recession, statistical analyses indicate substantial improvement. Other strengths favoring a strengthening euro include increased international usage and higher foreign currency reserve weightings. These are expected to increase given the positive exchange rate developments and future EMU accessions. 
While these developments are promising, the currency has at least one significant obstacle to overcome. The most glaring issue is the Euro area's fiscal policies. The inability to coordinate a standard policy could limit the region's ability to grow. Furthermore, the budgetary and debt constraints could prove debilitating to individual nations. Although empirical research suggests this would not be the case, the region has not undergone significant trials to determine the reality. Another concern is the European Central Banks' use of the "Harmonised Index of Consumer Prices" (HICP) to gauge inflation. While the ECB seems to be meeting its targets, many question its accuracy. Even if the banker's inflation management is satisfactory, it is vitally important that the ECB base its monetary policies on correct information.

The Euro area's strengths favor a larger economy, one that may challenge the United States' for supremacy. Furthermore, the currency's usage and reserve trends support substantial increases in demand. The weaknesses, while concerning, are not as tangible as the strengths. Based on these analyses, it is reasonable to project a strengthening euro over the next ten years.

\section{SUMMARY AND CONCLUSION}

The purpose of this paper was to evaluate the Euro area and the euro using a list of factors to determine the currency's ten year trajectory. Various journal articles were used to compare a variety of views regarding the euro and its underlying economy. The criteria on which to make these assessments included economic growth, inflation, fiscal policy, international usage and global foreign currency reserve weightings.

After reviewing the voluminous literature available, the findings indicated that the Euro area has made significant progress in only ten short years. The currency's demand has been increasing and the underlying economy seems poised for additional growth. These and other factors supported this paper's prediction that the euro will strengthen in relation to its peers within the next decade.

\section{ABOUT THE AUTHOR}

Dr. Balasundram Maniam is a Professor of Finance and chair of the General Business and Finance Department at Sam Houston State University. He holds a Ph.D. in finance from the University of Mississippi (1992). He has published numerous referred journals articles. He is currently serving as the editor of the Journal of International Business Research.

Mr. Tony Mouser holds a MBA from Sam Houston State University and has presented several papers in the area of finance.

Dr. Hadley Leavell is a Professor of Finance at Sam Houston State University. He holds a DBA in finance from the Louisiana Tech (1991). He has published numerous referred journals articles.

\section{REFERENCES}

1. Bergsten, C. F. (1997, Jul - Aug). The Dollar and the Euro. Foreign Affairs, 76 (4) 83-95. Council on Foreign Relations.

2. Bieling, H.-J. (2006, August). EMU, Financial Integration and Global Economic Governance. Review of International Political Economy, 13 (3) 420-448. Taylor \& Francis, Ltd.

3. Blanchard, O. (2004, Autumn). The Economic Future of Europe. The Journal of Economic Perspectives, 18 (4) 3-26. American Economic Association.

4. Blanchard, O., Giavazzi, F., \& Sa, F. (2005). International Investors, the U.S. Current Account, and the Dollar. Brookings Papers on Economic Activity, 1 1-49. The Brookings Institution.

5. Cecchetti, S. G., Wynne, M. A., Galí, J., \& and Propper, C. (2003, October). Inflation Measurement and the ECB's Pursuit of Price Stability: A First Assessment. Economic Policy, 18 (37) 395-434. Blackwell Publishing on behalf of the Centre for Economic Policy Research, Center for Economic Studies, and the Maison des Sciences de l'Homme.

6. (2010). Currency Composition of Official Foreign Exchange Reserves. International Monetary Fund (IMF). 
7. Davis, B. (2010, June 8). For Euro: More Lows, Rebound. Retrieved 06 2010, from Wall Street Journal Online: http://online.wsj.com/article/SB10001424052748703303904575292074119031264.html

8. Dominguez, K. M. (2006, Fall). The European Central Bank, the Euro, and Global Financial Markets. 20 (4) 67-88. American Economic Association.

9. $\quad$ Exchange Rate Conundrums. (2003, July - August). Economic and Political Weekly, 38 (30) 3123 - 3125. Economic and Political Weekly.

10. Flatness, A., Whitake, E. M., \& Yuskavage, R. E. (2009, July). Annual Revision of the U.S. International Accounts. Retrieved 06 2010, from www.bea.gov: http://www.bea.gov/scb/pdf/2009/07\%20July/0709_itaannual.pdf

11. Force, I. R. (2006, February). Occasional Paper Series No. 43. Retrieved 06 2010, from European Central Bank Website: http://www.ecb.int/pub/pdf/scpops/ecbocp43.pdf

12. Frankel, J. A. (1995, July - August). Still the Lingua Franca: The Exaggerated Death of the Dollar. Foreign Affairs. Council on Foreign Relations.

13. Galí, J., Perotti, R., Lane, P. R., \& Richter, W. F. (2003, October). Fiscal Policy and Monetary Integration in Europe. Economic Policy, 18 (37) 533-572. Blackwell Publishing.

14. Garrett, G. (2000, Spring). Capital Mobility, Exchange Rates and Fiscal Policy in the Global Economy. Review of International Political Economy, 7 (1) 153-170. Taylor \& Francis, Ltd.

15. Goldberg, L. S., Engel, C., \& Portes, R. (2005). Trade Invoicing in the Accession Countries: Are They Suited to the Euro? NBER International Seminar on Macroeconomics, 357-402. (T. U. Press, Ed.)

16. Honohan, P., Lane, P. R., Ventura, J., \& and Begg, D. (2003, October). Divergent Inflation Rates in EMU. Economic Policy, 18 (37) 357-394. Blackwell Publishing.

17. Kaminsky, G. L. (1998, March). Leading Indicators of Currency Crises. Staff Papers - International Monetary Fund, 45 (1) 1-48. Palgrave Macmillan Journals on behalf of the International Monetary Fund.

18. Kamps, A. (2006, August). The Euro as Invoicing Currency in International Trade. Retrieved 062010 , from European Central Bank Website: http://www.ecb.int/pub/pdf/scpwps/ecbwp665.pdf

19. Pelagidis, T., \& Desli, E. (2004, Spring). Deficits, Growth, and the Current Slowdown: What Role for Fiscal Policy? Journal of Post Keynesian Economics, 26 (3) 461 - 469.

20. Portes, R., Rey, H., De Grauwe, P., \& Honkapohja, S. (1998, April). The Emergence of the Euro as an International Currency. Economic Policy, 13 (26) 305 -343. Blackwell Publishing. 


\section{NOTES}

